\title{
Б.Ө. Алтынбасов
}

Бристоль университеті, Ұлыбритания, Бристоль қ. e-mail: altynbasov@yandex.ru

\section{ЖАһАНААНУАЫҢ ҚАЗАҚСТАННЫҢ ЖОҒАРЫ БІАІМ САААСЫНА ЫҚПААЫ: САЯСИ-ҚҰҚЫҚТЫҚ, АСПЕКТІАЕРІ}

\begin{abstract}
Бұл жұмыстың мақсаты ретінде жаһанданудың теориялық және тарихи аспектілерін және оған негіз болған саяси және құқықтық актілерді талдау, жекелеген елдердің білім саласына ықпалын ашып қарастыру. Зерттеу жұмысы сапалық зерттеу әдісі негізінде құжаттамалық анализге сүйеніп жүргізілді. Жаһанданудың жоғары білім саласында қалай пайда болғанын анықтау үшін Вашингтон Келісімі, Болон процесі және өзге де саяси құбылыстардың құқықтық актілері құжаттамалық анализ арқылы қарастырылды. Қосымша ақпараттар түрлі ресми құжаттар мен ақпарат көздерінен қайталама талдау әдісін қолдану арқылы алынды. Сондай-ақ, осы тақырыпта жүргізілген ғылыми еңбектерге тарихи және логикалық талдау әдістері арқы^ы саралау жұмыстары жүргізілді.

Зерттеу жұмысының нәтижесінде жоғары білім саласындағы жаһандану саясаты неолибералдық концепциямен ұштасатыны және ол Батыстың Аамыған елдерінің бастамасымен жүзеге асырылғаны анықталды. Жоғары білім саласында неолибералдық идеялардың таралуына Вашингтон Келісімі және халықаралық қаржы ұйымдарының қатысы бар екені көрсетілді. Жоғары білім саласындағы мәселелерді нарықтық қатынастар арқылы шешу идеясы АҚШтың экономист ғалымдарының кеңес беруімен жасалғаны және ол Американың экономикалық үстемдігін орнатуға бағытталғаны туралы тұжырым жасалды.

Басқару жүйесінің тиімді қызмет етуі университеттің жалпы тиімділігіне ықпал ететін басты фактор екені және бұл бағытта қазақстандық университеттерде әлі де жетілдіру жұмыстары жүргізілу қажеттігі ұсынылды. Зерттеу барысында жасалынған ұсыныстар мен қорытындылар жоғары білім саласындағы басқару моделіне қатысты реформа жүргізуде уәкілетті органдармен ескеріледі деген үміт бар. Сондай-ақ, бұл мақала осы тақырыпта келешекте жүргізілетін зерттеу жұмыстарына ғылыми негіз болады деп күтіледі.
\end{abstract}

Түйін сөздер: жаһандану, неолиберализм, мемлекеттік университеттер, басқару жүйесі, құқық, және саясат.

\section{B.O. Altynbassov \\ University of Bristol, UK, Bristol, e-mail: altynbasov@yandex.ru \\ The impact of globalization on higher education in Kazakhstan: political and legal aspects}

The purpose of this paper is to carry out a theoretical and historical analysis of political and legal acts of internationalization and to identify the impact of globalization processes on higher education in certain countries. The research is conducted by documentary analysis based on the qualitative research method. The origins of global trends in higher education, such as the Washington Consensus, the Bologna Process, and other political phenomena, have been explored through documentary analysis of legal acts. Additional materials for research were obtained from various official documents and information sources using the method of secondary data analysis. Also, research papers on this topic were analysed using the methods of historical and logical analysis.

As a result of the study, it was revealed that global policy in the field of higher education is based on a neoliberal idea and was initiated by Western countries. It was noted that the Washington Consensus and some international financial institutions were involved in the dissemination of neoliberal ideas in higher education. It was concluded that the idea of solving social issues in higher education through the market model was developed on the advice of American economists and was aimed at establishing American economic dominance.

It has been suggested that the effective functioning of the governance system is a key factor affecting the overall efficiency of the university, and in this regard, Kazakhstani universities still need to be improved. It is hoped that the recommendations and conclusions of the study will be taken into account 
by the authorities when reforming the governance system in higher education. It is also expected that this article will serve as a theoretical underpinning for future research on this topic.

Key words: globalization, neoliberalism, state universities, governance, law and politics.

\author{
Б.О. А^тынбасов \\ Бристольский университет, Великобритания, г. Бристоль, \\ e-mail: altynbasov@yandex.ru
}

ВАияние глобахизации на высшее образование в Казахстане: политические и правовые аспекты

\begin{abstract}
Цель данной работы - провести теоретический и исторический анализ политических и правовых актов интернационализации и проанализировать влияние глобализационных процессов на высшее образование отдельных стран. Исследование основано на документальном анализе методом качественного исследования. Происхождение глобальных тенденций в сфере высшего образования, таких как Вашингтонское Соглашение, Болонский процесс и Аругие политические явления, было изучено посредством документального анализа правовых актов. Аополнительные материалы Аля исследования были получены из различных официальных документов и источников информации с использованием метода вторичного анализа данных. Также были проанализированы научные работы по данной теме методами историко-сравнительного и могического анализов.

В результате исследования было выявлено, что глобальная политика в сфере высшего образования основана на неолиберальной концепции и была инициирована развитыми Западными странами. Было отмечено, что страны Вашингтонского Соглашения и ряд международных финансовых организаций участвовали в распространении неолиберальных идей в высшем образовании. Был слелан вывод, что илея разрешения социальных проблем в области высшего образования через рыночные отношения была разработана по совету американских экономистов и была направлена на установление экономического господства Америки.

Высказано предположение, что эффективное функционирование системы управления является ключевым фактором, влияющим на общую эффективность университета, и в этом отношении казахстанские университеты все еще нуждаются в улучшении. Есть надежда, что рекомендации и выводы исследования будут учтены уполномоченными органами при реформировании системы управления в высшем образовании. Также ожидается, что эта статья станет научной основой Аля будущих исследований по данной теме.
\end{abstract}

Кмючевые слова: глобализация, неолиберализм, государственные университеты, управление, право и политика.

\section{Kipicne}

Соңғы екі онжылдықта Қазақстан Республикасы жоғары білім саласын әлемдік білім кеңістігіне енгізу саясатын ұстануда. Нәтижесінде, қазақстандық жоғары оқу орындары әлемнің алдыңғы қатарлы университеттері мен ғылыми-зерттеу орталықтарымен әріптестік орнатып, бірлесіп білім бағдарламасын жасап, ғылыми-зерттеу жобаларын жүргізуде. Алайда, жаһандану барысында қазақстандық жоғары білім саласына Батыс елдері саясатының ықпалы зор болып отыр, әсіресе, Еуропаның жоғары білім кеңістігіне ену және Болон процесі барысында шығарылған актілер мен ұсыныстар министрлік тарапынан белсенді түрде енгізілуде. Сондай-ақ, АҚШ-тың әлемдік деңгейдегі университеттерінің басқару моделі мен білім беру жүйесі қазақстандық ғылыми-зерттеу университеттерде үлгі ретінде қолданылуда. Осы себепті де, бұл жұмыста жаһандану жағдайында мемлекеттік университеттердің басқару жүйесінде жүргізіліп жатқан реформаларды зерттеу көзделіп отыр.

Еуропаның жоғары білім саласындағы саясаты осы уақытқа дейін Еуропа елдерінің экономикасы шеңберінде жүзеге асырылып келді, алайда, соңғы жылдары еуропалық аймақтың трансформациялануы және әлемнің өзге аймақтарында белсенді таралуы байқалып отыр (Robertson 2010). Сондай-ақ, мұндай саясат Еуропаның білім аймағы ретінде өзге аймақтарда және жаһандық деңгейде көшбасшылық жасауға құқықтық платформа болып, жаңа мүмкіндіктер беріп отыр. Қазақстан Болон процесіне мүше мемлекет болғандықтан, Еуропаның жоғары білім кеңістігінің АҚШ-қа қарағанда қазақстандық жоғары оқу орындарына ықпалы зор болып отыр.

Болон процесінде университеттің басқару моделі туралы нақты айтылмағанымен, неолиберализм идеяларының жүзеге асырылуы, 
университетке сырттан қаржы тарту, шетелдік студенттерді тарту, университеттер мен өнеркәсіп компаниялары арасында тығыз әріптестік орнату сияқты саясат Еуропалық Комиссия тарапынан белсенді қолдау тауып отыр. Еуропалық Комиссияның саясаты бойынша университеттер өзінің стейкхолдерлері, яғни студенттер, мемлекеттік органдар және қоғам алдында міндеттемелерге ие және әлеуметтік құндылықтарды жоғары қоюы тиіс (European Commission 2003). Осындай талаптар қою арқылы, Болон процесі Еуропада және одан басқа да аймақтарда ұлттық деңгейде жоғары білім саласын басқаруды реформалауда маңызды рөл атқарып отыр (Robertson 2010). Нәтижесінде, жекелеген елдердің жоғары білім саласы қайта құрылып, модернизацияланып және нарыққа бейімделіп келе жатыр (Altbach 2004). Мұндай реформалар негізінде университетті басқару жүйесінде мемлекеттің рөлі өзгеріп, университеттер мен өнеркәсіп компаниялары және өзге де стейкхолдерлері арасындағы қатынастар жаңа бағытта дамуда.

Әрине, Қазақстанның жоғары білім жүйесіне басқа да аймақтардың ықпалы бар. Мысалы, шетелде оқитын қазақстандық студенттердің басым көпшілігі Ресейде оқиды. Қазақстанның солтүстік жағында Ресейге шекаралас облыстарда орыстар көп орналасқан және олар Ресейде білім алуды жөн көреді. Мысалы, 2015 жылы шетелде оқитын студенттердің жалпы саны 48875 болыпты, соның ішінде 35106 студент Ресейде оқыпты (OECD 2017). Сондай-ақ, Қазақстан КСРО-ның құрамындағы республикалардың бірі болғандықтан, орыс тілі ортақ тіл және ТМД шеңберінде Ресейдің саяси-экономикалық ықпалы жоғары екенін де айта кеткен жөн. Алайда, тәжірибе көрсетіп отырғандай, әлемдік білім кеңістігінде Ресейдің жоғары білімі мен ғылымы Қазақстан үшін аса қызығушылық тудырмайды. Сол сияқты, Қытай Үкіметі де қазақстандық түлектерге жыл сайын мыңдаған тегін гранттар ұсынады және оқу ақысы Батыс елдеріне қарағанда анағұрлым төмен. Алайда, соңғы жылдары Қазақстанда азаматтық қоғам арасында Қытайдың адам құқықтарын бұзуы, мұсылмандарды концлагерлерде қамауына қатысты қатты сын айтылуда. Сондай-ақ, 2016 жылы Қазақстанның көптеген қалаларында Қытай экспансиясына қарсы орын алған ереуілдердің нәтижесінде қазақстандықтардың арасында Қытайда білім алуға қатысты аса құштарлық байқалмайды. Жалпы алғанда, Болон процесімен салыстырғанда еліміздің жоғары білім саясатында Ресей мен Қытайдың саяси ықпалы жоғары емес. Ислам қауымдастығына қатысты айтатын болсақ, Қазақстанға ислам діні 8-9-ғасырларда келген және 1917 жылға дейін мұсылман мешіттері мен олардың жанындағы медреселерде араб тілінде білім берілген (Әбдірәсілқызы 2013). Бүгінгі танда, Араб елдерінде діни білім алу діндарлар арасында құрметке ие. Алайда, Қазақстан зайырлы ел болған соң, Қазақстанның жоғары білім саласында Араб елдерінің саяси ықпалы аса байқалмайды.

Жалпы алғанда, Қазақстанның жоғары білім саласына басқа аймақтарға қарағанда Батыс елдерінің ықпалы жоғары болып отыр және бұл мәселені теориялық және тәжірибелік тұрғыдан зерттеу өзекті деп саналады. Бұл жұмыста біріншіден, қазақстандық жоғары білім саласында жаһанданумен байланысты қандай реформалар жүргізілді және оның нәтижесі қандай болып жатыр, екіншіден, жаһандану процесінде қандай қарама-қайшылықтар мен кедергілер туындағаны және үшіншіден, жаһанданумен байланысты университет басқару жүйесінде орын алып жатқан реформалар қарастырылып, қазақстандық университеттердің басқару моделіндегі мәселелер талқыланып, жекелеген ұсыныстар беріледі.

\section{Зерттеу әдісі}

Зерттеу жұмысы сапалық зерттеу әдісі негізінде құжаттамалық анализге сүйеніп жүргізілді. Жаһанданудың жоғары білім саласында қалай пайда болғанын анықтау үшін Вашингтон келісімі, Болон процесі және өзге де саяси құбылыстардың құқықтық актілерін құжаттамалық анализ арқылы қарастыру қажет болды. Қосымша ақпараттар алу үшін деректерді қайталама талдау әдісі арқылы түрлі ресми құжаттар мен ақпарат көздерінен мәліметтер алынды. Сондай-ақ, осы тақырыпта жүргізілген ғылыми еңбектерге тарихи және логикалық талдау әдістері арқылы саралау жұмыстары жүргізілді.

Салыстырмалы зерттеу саласындағы ғалымдардың пікірінше, білім саласында зерттеу жүргізгенде зерттеу тақырыбын тарихи, саяси, экономикалық, әлеуметтік және өзге де контексте қарастыру оң нәтиже береді (Phillips, Schweisfurth 2014). Түрлі контексте зерттеу жүргізу арқылы білім саласындағы мәселелерді тереңірек түсініп, жан-жақты талқылауға мүмкіндік алдық. Мысалы, тарихи және саяси кон- 
тексте талдау арқылы неолиберализм идеяларының шығу тарихына және оның пайда болуына қандай саяси негіз болғаны анықталды. Экономикалық тұрғыдан талқылау арқылы білім саласындағы неолибералдық реформалардың экономикалық себептері анықталды.

\section{Негізгі бөлім}

Қазақсттанның жогары білім саласына қысқаша тарихи шолу

Тарихи тұрғыдан қарасақ, Қазақстанда жоғары білімнің пайда болуы XX ғасырдан бастау алады. Қазақстанда алғашқы 5 институт 1920 жылдардың басында пайда болды, атап айтқанда Бөкеев, Семей, Қазақ, Орынбор халық ағарту институттары және Алма-Атадағы Қазақ педагогикалық институты (Huisman және басқалар 2018). 1932 жылға дейін ауыл шаруашылығы, медицина және ветеринария саласында тағы 15 институт құрылды. Екінші дүниежүзілік соғыс кезінде кейбір Мәскеу университеттері Алматыға көшірілді. Мысалы, Бүкілодақтық жұмысшыларға арналған заң институты көшіп келіп, көптеген профессорлар мен ғылыми зерттеу материалдары келді. Соғыстан кейін сол ғалымдардың бірқатары Қазақстанда қалды. 1980 жылдардың аяғында Қазақстанда 287,400 студент оқитын 55 жоғары оқу орны болды (Huisman және басқалар 2018).

Кеңес Одағы тарағанға дейін Қазақстанда жоғары білім толығымен тегін беріліп, студенттер мен жас ғалымдар жұмыспен қамтамасыз етіліп, үйді тегін алып, ғалымдар мен оқытушыпрофессорлық құрамның жалақысы жоғары болды. Ол заманда ғылыми-шығармашылықпен айналысқан адамдар қоғамның элитасы ретінде саналып, құрмет пен марапатқа ие болды. Бір сөзбен айтқанда, мемлекет білім мен ғылымға жеткілікті қаражат бөліп отырды және мемлекеттің білім саласындағы саясаты мен стратегиясы дұрыс болды. Әрине, бұл кеңестік кезде мемлекет өзінің әлеуметтік функциясын лайықты деңгейде орындағанын және білім мен ғылымның қоғамдық игілік ретінде саналғанын көріп отырмыз.

Кеңес Үкіметінің құлауымен бірге экономиканың барлық саласында жаппай реформалар орын алды. Әрине, білім саласында да күрделі реформалар басталды. Ол ең алдымен, экономикалық дағдарыспен байланысты қаржылық тапшылықтың салдарынан болды. Жоғары оқу орындарында ақылы бөлімдер ашылып, ақылы түрде кеңес беру, жеке меншік оку орындарының ашылуы сияқты құбылыстар орын алды. Балабақшалардан бастап жоғары оқу орындарына дейін мемлекеттік меншіктегі ғимараттар мен басқа да активтерді жекешелендіру процесі басталды. Бұл құбылыстар сол кездері әлемдік экономикада АҚШ пен Ұлыбританияның бастауымен жүргізілген неолибералдық саясаттың нәтижесі еді. Неолибералдық саясат жаһанданудың негізінде пайда болған үрдіс және оның салдары туралы төменде айтатын боламыз. Яғни, білім саласында нарықтық қатынастар пайда болып, тауар-ақша қатынастары үстемдік ете бастады.

1999 жылы 19 маусымда Еуропаның 29 елінің өкілдері ортақ Еуропалық жоғары білім кеңістігін қалыптастыру идеясымен Болон қаласында (Италия) Болон Декларациясына (Bologna Declaration 1999) қол қойды. Осы Декларацияның басты мақсаты Еуропаның жоғары білімін әлемге танымал ету және өзге аймақтарға ықпалын күшейту еді. 2010 жылы Қазақстан Республикасы Болон Декларациясына қол қойып, ресми мүшесі атанды. Іс жүзінде, Қазақстанның жоғары білім саласында 2000 жылдардан бастап Батыстық жүйеге сәйкес білім беру, кадр дайындау, шетелдік университеттермен әріптестік орнату сияқты құбылыстар пайда болды. Болон процесі жоғары білім саласындағы аймақтық кеңістік орнатуға бағытталғанымен, Қазақстан үшін жаһанданудың бір белгісі ретінде қарастырылды. Зерттеушілердің пікірінше, «жаһандану кезінде жекелеген мемлекеттердің экономикасы өзара тәуелді болып ортақ белгілерге ие болады. Мұндай жағдайда мемлекеттердің заңнамалық жүйесі интеграция жасалып, өзара сауда нарықтық қатынастар дами түседі» (Van der Wende 2004). Көріп отырғанымыздай, жоғары білім саласында да мемлекеттер арасында екіжақты және көп жақты келісімдер жасалып, ортақ нормативтік база қалыптаса бастайды. Осының нәтижесінде, Еуропа мен Орталық Азия елдерінің жоғары білім саласындағы саясаты бірігіп, ортақ кеңістік қалыптасу үстінде.

Жаһанданудың Қазақстанның білім жүйесіне ықпалын қарастыратын болсақ, оның көп ұтымды жақтары бар. Қазақстан білім саласындағы көптеген халықаралық ұйымдардың мүшесі болып, білімнің сапасын бағалау және аккредитациялау жүйелерін енгізді. Халықаралық стандарттар бойынша білім беріп, университеттер ішінара автономияға ие болды. Ал кейбір университеттер әлемнің жетекші университеттерімен екіжақты және көпжақты келісімдер арқылы серіктестік қарым-қатынас 
орната бастады. Жаңадан құрылған Назарбаев Университеті Пенсильвания университетімен (АҚШ) және Кембридж университетімен (Ұлыбритания) және әлемнің басқа да жетекші университеттерімен серіктестік байланыс орнатты. Назарбаев Университетінің басты саясаты - Астанада инновациялық-білім Хабын құруға бағытталған әлемдік деңгейдегі университет моделін құру (Nazarbayev University Strategy 2013). Бұл басқару моделі Назарбаев Университетіне ұйымдастырушылық, қаржылық және академиялық қызметте толығымен автономды және ерекше құқықтық мәртебеге ие болуға мүмкіндік береді. Университеттің жеке қамқоршылық кеңесі мен қоры, сонымен қатар тәуелсіздік пен автономияны қамтамасыз ететін атқарушы басқару органдары бар. Қамқоршылық кеңестің мүшелері Үкіметтің және орталық мемлекеттік органдардың жоғары деңгейдегі қызметкерлері, ал төрағасы - экс-президент Н. Назарбаевтың өзі. Назарбаев Университеті білім беруде толық автономияға ие және Білім және ғылым министрлігіне есеп бермейді. Студенттер мен оқытушылардың жоғары ұтқырлығын қамтамасыз ету үшін сабақ беру және ғылыми зерттеу жұмыстары тек ағылшын тілінде жүргізіледі. Сонымен қатар, түлектердің дипломдары халықаралық деңгейде танылады (Bilyalov 2018). Осы себепті де, бүгінгі таңда Назарбаев Университетінің тәжірибесі бүкіл елде кеңінен таралуда.

Сондай-ақ, Еуропалық жоғары білім кеңістігіне енген соң қазақстандық жоғары оқу орындары әлемдік рейтингтерге (QS World University Rankings және т.б.) белсенді қатыса бастады. Білім сапасын сырттан бағалаудың механизмі ретінде университеттердің еуропалық аккредитациядан өту міндеттілігі енгізілді және ел ішінде жеке меншік тәуелсіз аккредитациялық компаниялар пайда болды (Anafinova 2020). Яғни, білім саласындағы министрліктің бірқатар бақылау және бағалау функциялары шетелдік және ел ішіндегі жеке компаниялардың өкілеттігіне берілді.

Дегенмен, Қазақстан бұрынғы Кеңес Үкіметінің мүшесі болғандықтан, жоғары білім саласының басқару жүйесі және университеттердің басқару органдары Шығыс және Орталық Еуропа елдерінің университеттік басқару жүйесіне ұқсайды. Тіпті, университеттің басқару органдары мен лауазымды тұлғаларының атаулары да түбі бір екенін байқауға болады. Мысалы, университеттік кеңес, ректор, проректор, декан сияқты органдар мен лауазымдар Қазақстанда да солай аталады және сондай функцияларды жүзеге асырады. Ал Ұлыбритания мен АҚШтың университеттерінде қызмет ететін Board of Regents, Regent House, Senate, Court, Chancellor сияқты басқару органдары мен лауазымдары қазақстандық университеттерде кездеспейді.

Халықаралық интеграцияны одан әрі дамыту мақсатында Қазақстан Республикасында Білім мен ғылымды дамытудың 2020-2025 жылдарға арналған Мемлекеттік бағдарлама қабылданды. Аталмыш Бағдарламаның негізінде отандық жоғары оку орындарын одан әрі дамытудың бірқатар индикаторлары бекітілді. Атап айтқанда, Бағдарламаның міндеттерінің бірі ретінде «Ғылыми әзірлемелердің нәтижелілігін арттыру және әлемдік ғылыми кеңістікке интеграциялануын қамтамасыз ету» көзделген (Мемлекеттік бағдарлама 2020-2025). Көріп отырғанымыздай, жаһандануға жауап ретіне университеттер мен ғылыми орталықтардың басқару жүйесіне әлемнің озық тәжірибесін енгізу көзделіп отыр. Сондай-ақ, университеттердің басқару жүйесінде де күрделі реформалар жүргізілуде. Атап айтқанда, ұлттық және мемлекеттік университеттерде корпоративтік басқару моделін енгізу, университет пен өзге де мүдделі тараптардың арасында әріптестік орнату, эндаумент қорларын құру сияқты Батыстың алдыңғы қатарлы университеттерінде бар институттарды енгізу жүргізілуде. Әрине, мұндай саясат отандық жоғары оқу орындарының қаржылық жағдайын көтеріп, сапалы білім мен ғылыми зерттеу жұмыстарын жүргізуге мүмкіндік алу үшін жасалып отырған шаралар. Дегенмен, жаһанданудың дамушы елдерге келтірген жағымсыз тұстары да бар, сондай-ақ, университетті басқару жүйесінде де жекелеген құқықтық және ұйымдастырушылық мәселелер орын алып отыр. Осы және өзге де мәселелерді келесі тарауларда қарастырамыз.

Жаһанданудың ұлттық білім жүйесіне ыққпаль

Жаһандану проблемасы көпқырлы және жаһандану тұжырымдамасы туралы әртүрлі пікірлер де бар және ол көп жағдайда ғалымдар мен эксперттердің жеке көзқарасына байланысты. Жоғары білімнің жаһандануын жақтаушылар арасында да қарама-қайшы пікірлер бар екенін ескерген жөн (Parjanadze 2009). Мысалы, неолибералистер мен марксистер неолибералды жаһандану қазірдің өзінде жүріп жатыр деп келіскенімен, оның салдары туралы қарамақайшы пікір ұстанады. Жаһанданудың қалай пайда болғаны және оның білім саласына ықпалы 
қаншалықты болғанын Сюзан Робертсон және оның әріптестері жазған «Globalisation, Education and Development: Ideas, Actors and Dynamics» еңбекте жан-жақты айтылған. Аталған монографияда жаһанданудың неолиберализм идеяларын білім саласына енгізгенін, АҚШ және өзге де батыстың дамушы елдері бұл саясатты 1980 жылдары Вашингтон Консенсусі арқылы жүзеге асырғаны көрсетілген. Бұл саяси-экономикалық бағдарлама Жүйелі кқайта құру (Structural Adjustment Polices) деп аталып, Әлемдік Банк, Халықаралық валюталық қор, АҚШ-тың Казына Департаменті сияқты халықаралық қаржы институттарының көмегімен жүргізілгені және мұның астарында үлкен саясат жатқаны айтылған. Түрлі ғылыми әдебиеттер мен халықаралық актілерге сүйене келе, Робертсон және оның әріптестері экономикасы нашар және дамушы елдердің білім саласына Вашингтон Консенсусі зиян әкелді деген қорытынды жасайды. Нәтижесінде, Пост-Вашингтон Консенсусі жүзеге асырылып, жаһандық экономикаға тағы жаңа ұсыныстар жасағанын айтады (Robertson 2007). Жалпы алғанда, аталған ғылыми еңбекте батыс елдерінің бастамасымен жүргізілген экономикалық жаһандану батыстық емес елдерге, әсіресе дамушы және дамымаған елдерге жағымсыз ықпал еткені көрсетілген.

Басқа ғалымдардың пікірінше, жаһандану әлемдік экономикада АҚШ-тың үстемдігін орнату саяси концепциясы деп түсініледі (Marginson, Mollis 2001). Бұл пікірдің белгілі бір деңгейде негізді екенін Американың тарихынан көруге болады. 20-ғасырдың орта шегінде АҚШ-тың Чикаго Университетінің экономист ғалымдары Смиттің классикалық либералды экономикасына сүйене келе жаңа экономикалық даму саясатын ұсынды. Экономикадан Нобель сыйлығының лауреаты Фридман өз еңбектерінде әлеуметтік мәселелерді шешуде мемлекеттік-құрылымдық басқаруға қарағанда нарықтық қатынастарды көтермелу тиімді екенін алға тартты. Қайта құрылған либералды экономикалық концепция немесе неолиберализм идеялары қоғамдық мүдделерді нарықтық қатынастар арқылы қамтамасыз етуде ұтымды деп танылды. Оның жақтаушылары нарықтағы бәсекелестік арқылы білім саласында тиімділік, жауапкершілік және инновацияға қол жеткізуге болады деп сенді. Бұл саяси-экономикалық концепция «Жаңа мемлекеттік басқару» деген атпен белгілі болды (Branford 1988). Осы кездері мемлекеттік сектордағы экономика тиімсіз және экономикалық дағдарысқа әкелуі мүмкін деген болжамдар жасалды. Чикаго Университетінің экономистері жасаған бұл концепция 1970 жылдары Латын Америка елдерінде сынақтан өтті. Білім саласында мемлекет пен жеке сектордың әріптестігіне негізделген жүйе, яғни ваучерлер, несиелер беру механизмдері орта білім саласында жаппай енгізілді (Verger 2012). Чилиде жүргізілген экономикалық реформа әдебиетте «Чилидің экономикалық кереметі» деп аталып кетті (Glewwe 2014). Дегенмен, Американың бұл саясаты Чилиде саяси тұрақсыздық орнатып, әскери төңкеріске әкеп соқты, Чили экономикасының басты тірегі болған ауыр өнеркәсіп саласы дағдарысқа ұшырап, АҚШ-тың бақылауына түсті. Нәтижесінде, АҚШ-тың қаржылық және экономикалық саясатының негізінде Латын Америка елдерінде, яғни Чили, Бразилия, Аргентина, Перу сияқты елдердің білім саласында неолибералдық қатынастар орнады (González 2013). Әрине, АҚШ-тың үстемдік орнату саясаты мұнымен тоқтаған жоқ.

1980 жылдары әлемдік экономикада жаһандану идеялары кең тарай бастады. Мұны Батыстың экономикалық әдебиетінен Вашингтон келісімі (Washington Consensus) және өзге де саяси бастамалардың негізінде жүргізгенін байқауға болады. Алғаш рет дамушы елдерде неолиберализм саясатының таралуына 1982 жылы Мексикада орын алған қаржылық дағдарыс себеп болды (Branford 1988). Сол кездері Мексика, Бразилия, Аргентина сияқты Латын Америка елдері өнеркәсіп пен инфрақұрылымды дамыту мақсатында Халықаралық қаржы институттарынан несие алған. Осы процестің барысында Мексика үлкен қаржылық қарызға түсіп, нәтижесінде шетелдік банктердің алдындағы қарызын жабуға қаржылық қабілеті жоқ болып шықты. Осы жағдайдан соң Әлемдік Банк пен Халықаралық валюталық қор тарапынан дамушы елдерге қатысты жаңа экономикалық құралдар қолданатын болды, яғни неолиберализм концепциясына негізделген экономикалық саясат. Бұл саясат Жүйелі қайта құру саясаты (Structural Adjustment Polices) (Berg 1994) деп аталды. Ғылыми әдебиетте осы саясаттың басталуына АҚШ пен Ұлыбританияның тікелей қатысы бар екені және бұл саясат өз кезегінде Маргарет Тэтчер мен Рональд Рейганның аттарымен байланыстырылып, Вашингтон келісімі (Washington Consensus) деген атпен әдебиетте таралды (Berg 1994).

Неолиберализм Америкада кең таралған концепция болып, Фридманның нарықтың заңдарымен әлеуметтік саладағы мәселелерді 
тиімді жолмен шешуге болады деген идеялары әлі де үстемдік етіп келеді деуге болады (Harvey, 2005). Себебі, АҚШ-тың жоғары білім саласы оған дәлел бола алады. Бүгіндері америкалық жоғары білімді басқару жүйесі нарықтық басқару моделіне жататын модель (Olsen 2007). Америкада жоғары білім алу аса қымбат екені әлемге белгілі және АҚШ-тың білім саласынан бюджетке жыл сайын миллиардтаған қаражат түседі және бұл маңызды экспорттық салалардың бірі болып саналады (Edwards 2000; Hursh, Wall 2011). АҚШ-та білім саласы нарық заңдарына тәуелді болғанымен, өз азаматтарына, тіпті шетелдік дарынды студенттерге арналған тегін оқу гранттары аз емес. Бұл да Американың адами капитал қалыптастырудағы ұтымды саясатының бірі деп айтуға болады. Кейбір ғалымдар жаһандану кезінде ұлттар мен елдердің мәдениеті араласып, бір-бірімен сіңісіп кетеді деп айтады (Waters 1995). Бұл пікірмен де келісуге болады, себебі, бүгінгі таңда, АҚШ пен Еуропа елдеріне білім алу мен ғылыммен айналысам деп жүз мыңдаған студенттер келіп, бір бөлігі сол жерлерде қалып жатыр. Яғни, мәдениет жағынан да Батыс елдері ұтылып жатқан жоқ, ең бастысы, әлемнен келген ең сапалы деген адами капиталды өз еліне қалдыруға мүмкіндігі болып отыр.

Осы мәселеге қатысты жаһандық жоғары білім саясатының маманы, әлемге танымал профессор Альтбах сын пікір айтты. Оның пікірінше, жаһандану барысында дамыған елдер мен дамушы елдердің арасында теңсіз қатынастар көрініс тауып отыр, яғни дамушы елдерден сапалы адами капиталдың дамыған елдерге кетуі, батыс елдерінің университеттерінде оқу ақысының дамушы елдердің студенттеріне салыстырмалы түрде жоғары болуы, ғылыми материалдардың онлайн базасы дамушы елдердің университеттері үшін өте қымбат болуы және тағы басқа жағымсыз жағдайлар орын алып отыр (Altbach 2004). Сондай-ақ, жоғары білімнің жаппай ақылы түрде болуы оның сапасын нашарлатып, жоғары білімнің массификация және макдональдизациясына әкеп соқты (Altbach 2004).

Жоғары білім саласындағы неолибералдық саясаттың жағымсыз жақтарына қатысты ғалымдар басқа да көзқарастар білдірді. «Неолибералдық концепция бойынша жоғары оқу орындары экономикаға қажетті жұмыс күшін дайындау ұйымдары ретінде қарастырылады. Бұл жағдайда студенттер мен оның ата-аналары университеттерді келешекте жұмысқа орналасудың құралы ретінде қарастырады» (Giroux 2002: 435). Яғни, студенттер жоғары білімді диплом үшін оқиды деген пікір қалыптасқан. Қазақстандық контекстеқарасақ, бұл көзқараспен де толығымен келісуге болады. Мысалы, соңғы 20 жылда елімізде ақылы түрде білім алу кең тарады. Лауазымдық қызметте отырған адамдардың биографиясын қарасаңыз, екінің бірінде екі, тіпті үш дипломы бар екенін көреміз. Әсіресе, жоғары білімді екінші мәрте жеке меншік жоғары оку орнында сырттай тәмәмдау кең етек жайды. Әрине, мұндай тенденция жеке меншік оқу орындарына тиімді және екі жылдық сырттай білім алушы студенттерге қатаң талаптар қойылмайды. Қысқасы, студентке де және университетке де тиімді мәміле. Жоғары білім саласында мұндай жағдайдың орын алып отырғанын уәкілетті мемлекеттік органдар да біледі және көзін жұмып отыр деуге болады. Алайда, жалған диплом алған түлектердің бір бөлігі мемлекеттік қызметке орналасып, өз кәсібін жетік игермей, мемлекеттік басқару жүйесінде негативті адами капиталды қалыптастырып жатқаны әлі де жеткілікті ескерілмей келеді.

Жаһанданудың дамушы елдерге келтірген зияны туралы басқа да халықаралық эксперттердің еңбектерінен көруге болады. Профессор Тикли жаһандануды сынға алып, Батыс елдерінің білім саласындағы саясаты батыстық емес елдерде білім саласындағы неоколониализм идеясын дамытады деп түсіндірді (Tikly 2004). Яғни, жаһандану кезінде ірі мемлекеттер әлсіз елдердің саясатына араласып, экономикалық үстемдік етіп, отарлау саясатын жүргізуді көздейді. Қазақстанның тарихына көз жүгіртсек, бұл пікірімен толық келісуге болады. Себебі, Қазақстан 200 жылдан астам Ресейдің колониясы болды және Кеңес Үкіметі құрамында болғанда да Мәскеудің саяси нұсқауымен өмір сүрді. Осының салдарынан, біздің елде халықтың басым көршілігі орыс тілінде сөйлеп, орыс мәдениетін бойына сіңірді. Кеңес үкіметі кезінде жоғары білімді тек орыс тілінде алуға мүмкіндік болды, яғни орыс тілін білмегендер мамандық ала алмай қара жұмыс істеуге мәжбүр болған. 1980 жылдары қазақтар өз елінде халық саны бойынша тек 30 пайызын құраған, яғни ұлт ретінде жойылып кету қаупі болған. Бұл Ресейдің колониялық және Кеңес үкіметінің неоколониалдық саясатының көрінісі. Бүгінгі күні де Қазақстан саяси-экономикалық тұрғыдан Ресейге тәуелді болып отыр. Сондықтан да, Ресей тарапынан неоколонизация саясаты бүгінде де жасырын түрде жүріп жатыр деуге болады.

Ресей империясының құрамына кіргелі, әсіресе Кеңес үкіметінің құрамына кіру кезінде, 
байлар мен жергілікті феодалдар жаппай қырғынға ұшыраған, 1917 жылдары азаматтық көтерілістерде миллиондаған қазақтар ашаршылық пен саяси қуғынға түсіп өлген. Тарихшылардың деректеріне сүйенсек келесідей ақпараттар аламыз. «Жоғарғы Кеңес жанынан құрылған комиссия 1931-1932 жылдардағы ашаршылықта 2 млн 300 мың қазақ қырылғанын айтты. Сонда Тұрар Рысқұлов 1918-1919 жылы 1 млн 214 мың адам қырылды десе, Мұхтар Әуезов 1921 жылғы ашаршылықта 1 млн 700 мың қазақ қырылды деді. Екеуін қоссақ, 3 млн-ға жуықтайды. Бұған 2 млн 300 мыңды қоссақ, он шақты жылдың ішінде 5 млн 200 мың қазақтан айырылғанымыз белгілі болады» (Қабидолла және басқалар 2020). Сондай-ақ, 37 жылдары Сталин репрессиясында куғынға ұшырап өлген жүз мыңдаған адамдарды айтып кету керекпіз. Яғни, 20-ғасырдың алғашқы жартысында қазақтың бүкіл саяси элитасы, ғалымдары, атақты жазушылар мен ақындар саяси көзқарастары үшін ату жазасына кесіліп, түрмелерде өлген. Үлкен көлемдегі геноцид 20 ғасырда қазақ елінің басынан өткен. Осы және басқа себептерге байланысты Кеңес үкіметінің тоталитарлық режиміне қатысты қоғамдық санада жағымсыз пікір сақталған.

Мұнда жаһандану кезінде орын алып отырған мәселелердің бір бөлігі ғана қарастырылып отыр және бұл жұмыстың көлемінде дамушы елдерде орын алып отырған жағымсыз жағдайлардың бәрін қамту мүмкін емес. Дегенмен, қазақстандық жағдайда жаһанданудың жоғары білім саласын басқару жүйесіне ықпалы жеке мәселе ретінде қарап өтуге тұрады. Сол себепті, келесі тарауда Қазақстанның университетті басқару жүйесінде жаһандану және неолибералдық саясаттың нәтижесінде қандай реформалар орын алып отырғанын қарастырамыз.

Жаһанданудың университетті басққарудың моделіне ықппаль: қ̧азақ̧стандық контекстегі көрінісі

Батыс елдерінің тәжірибесіне сүйенсек, жоғары білім саласы экономиканың маңызды сферасы екенін және университеттер жыл сайын бюджетке миллиондаған доллар немесе фунт стерлинг әкеп отырғанын көруге болады. Сондықтан да, дамыған елдерде меншік нысанына қармастан жоғары оку орындарының қызмет етуі және тиімді жұмыс істеуі мемлекеттің бақылауында болып келеді (Dixon, Coy 2007; Edwards 2000). Мемлекеттің жоғары оқу орындарын басқаруда маңызды рөл атқаратынын әлемдік тәжірибеден көруге болады. Мысалы, 1960-70 жылдары АҚШ, Ұлыбритания және
КСРО-да жоғары білім саласына мемлекет тарапынан үлкен көлемде қаржы бөлініп, жоғары білімді басқару саласында орталықтану орын алып, мемлекеттің рөлі жоғары болғаны белгілі (Huisman және басқалар 2018). Ал 1980 жылдардан бастап, жоғарыда аталғандай, Вашингтон Келісімінің негізінде жоғары білім саласына мемлекеттен бөлінетін қаржының көлемі шектеле бастады. Бұл жағдай жоғары білім саласында нарықтық қатынастардың орын алуына себеп болды. Сондықтан да, жаңа жүйеде жаңа басқару моделі қажет болып, мемлекет пен университеттер арасында жаңа арнада қатынастар қалыптаса бастады. Әрине, бұл жағдай әр елде әр түрлі көрініс тапты.

Доббинс университет басқарудың келесідей үш моделін бөліп қарастырады: университет ұжымымен басқарылатын модель, мемлекетпен басқарылатын модель және нарыққа бейімделген модель (Dobbins және басқалар 2011). Бұл жіктеуге сәйкес, посткеңестік елдер (Қазақстан, Ресей), Франция, Испания және Португалия мемлекетпен басқарылатын модельге кіреді. Яғни, университет басшылары мемлекеттік органдармен тағайындалады, білім беру жалпы стандарттарға сәйкес жүргізіледі, қаржы мемлекеттік бюджеттен түседі, сапаны қамтамасыз ету мемлекеттік органдармен жүзеге асырылады. Әрине, соңғы 10-20 жылда жаһандану процесінің негізінде ТМд елдері белсенді түрде батыс елдерінің жүйесін енгізу үстінде және бүгінгі таңда келесі екі модельдің де белгілерін байқауға болады. Ал екінші модель - университет ұжымымен басқарылатын модель, яғни Германия, Австрия және бірқатар посткоммунистік Орталық Еуропа елдерінде таралған Гумбольдтік модель. Бұл жүйеде университет пен мемлекет арасында әріптестік қатынас қалыптасып, университет алқалы түрде профессорлық құраммен басқарылады (Nybom 2003). 19-ғасырдың басында дәл осы басқару моделінде университеттердің ғылыми-зерттеу қызметіне барынша қолдау көрсетіліп, бүгінгі ғылыми-зерттеу университеттерінің негізі қаланды деп саналады. Ал үшінші - нарыққа бейімделген модельге АҚШ-ты жатқызуға болады. Бұл басқару моделінде неолиберализм идеялары басшылыққа алынады, яғни университеттер бизнес компаниялар тәрізді кәсіби мамандармен басқарылуы және қызметінің өнімділігіне қарай қаржыландырылуы тиіс деп саналады. Мұндай модельде білім тауар, инвестиция және стратегиялық ресурс ретінде танылады (Olsen 2007). 
Тарихи тұрғыдан қарасақ, университет ұжымымен басқарылатын модель алғаш рет Кембридж сияқты ескі университеттерде қалыптасқан, университет ұжымының дауыс беруі арқылы демократиялық жолмен басқарылатын жүйе. Кеңес үкіметі тұсында қазақстандық университеттер мемлекетпен басқарылатын модель арқылы басқарылып келді және әлі де толық оперативті және қаржылық автономияға қол жеткізе алмай отыр. Бірақ университет ішіндегі ішкі мәселелер де алқалы түрде университет ұжымымен басқарылды, яғни Ғылыми кеңестің рөлі маңызды болған. Бұл органның бүгінде де академиялық және басқару мәселелерінде рөлі жоғары. Алайда, Жаңа мемлекеттік менеджмент саясатында университеттер мейлінше кәсіпкерлікке икемді және өзін-өзі қаржыландыруы қажет жағдайда қарапайым оқытушылар мұндай функцияларды атқара алмайды және бұл модель тиімсіз деген пікірлер де бар (Donaldson, Preston 1995). Сол себепті де, бүгінгі таңда қазақстандық жеке меншік университеттер акционерлік қоғам нысанында бизнес компаниялар сияқты корпоративтік басқару нысанын енгізу үстінде. Олар мемлекетпен қаржыландырылмайды және студенттердің оқу ақысына тәуелді болып коммерциялық ұйым ретінде нарыққа бейімделген модель негізінде қызмет етеді.

Бүгінгі таңда болып жатқан басқару саласындағы реформалар жаһандану негізінде жүргізіліп отырғанында күмән жоқ. Осы уақытқа дейін ұлттық және мемлекеттік университеттер мемлекетпен басқарылып және қаржыландырылып келді және университет ішіндегі мәселелер алқалы түрде ұжым арқылы шешіліп отырды. 2010 жылдан бастап ұлттық және мемлекеттік университеттердің басқару жүйесін күрделі түрде реформалау жүргізілуде. Алғашында Қамқоршылық кеңестер құру туралы шешім қабылданды, бірақ ол біздің жүйеге сай келмейді екен деп таратылды. 2016 жылдан бастап Қамқоршылық кеңестердің орнына Байқау кеңестерін құру туралы министрліктің бұйрығы шықты, ал 2019 жылдан бастап директорлар кеңесіне ауысты. Он жылдың ішінде қазақстандық университеттер үш түрлі басқару моделін енгізіп көрді. Үстіміздегі жылы мемлекеттік университеттер құқықтық нысанын ауыстырып, корпоративтік басқару жүйесін, үшінші модельді енгізу үстінде. Мұндай күрделі реформаның жүргізілуіне мемлекеттің келесідей саяси даму бағыты негіз болды. 2019 жылы 11 қазанда шығарылған ҚР Үкіметінің
Қаулысымен 25 ұлттық және мемлекеттік университеттер шаруашылық жүргізу құқызындагы республикалық мемлекеттік кәсіпорын нысанынан коммерииялық емес акционерлік қзовам нысанына ауысатын болып, жарғылық капиталы 100 пайыз мемлекеттің меншігінде қалады деп бекітілді (ҚР Үкіметінің Қаулысы, 2019). Үкіметтің осындай қаулысынан кейін барлық университеттерде директорлар кеңесі, басқарма, ішкі аудит және өзге де корпоративтік басқару жүйесіне тән басқару органдары құрыла бастады. Бұл жерде басты орган ретінде директорлар кеңесі саналып отыр және сол орган университеттің тиімді жұмыс істеуінің кепілі болу керек деп Мемлекеттік Бағдарламада да көзделген. Алайда, бірқатар мемлекеттік университеттердің ресми сайтынан көргеніміздей, жаңа құрылған директорлар кеңесінің құрылу тәртібі және құрамы бұрынғы байқау кеңестерінің көшірмесіне ұқсайды. Университеттің Жарғысын талдай келе, оның ректоры - басқарма басшысы жалғыз акционерге, яғни Білім және ғылым министрлігіне тәуелді және есеп беріп отыратыны және кез келген уақытта қызметінен босатылатыны көрсетілген. Сондай-ақ, директорлар кеңесінің құрамында министрліктің басшылық қызметкерлері төрағалық ететіні және өзге мүшелері де мемлекеттік қызметтегі лауазымды тұлғалар екенін көруге болады. Бұл жағдай басқару жүйесіндегі белгілі бір қарама-қайшылықтардың бар екенін көрсетіп отыр. Корпоративтік басқару теориясын жақтаушылардың пікірінше, ұйымның корпоративтік басқару органдарында сол саланың кәсіпқой мамандары, ұйымның стратегиялық мақсаттарын түсінетін және жүзеге асыру жолдарын білетін, ұйымдастырушылық қабілеті мен кәсіби тәжірибесі бар, қаржы салуға мүдделі тараптарды тартуға мүмкіндігі бар тұлғалар мүшелік ету қажет (Hillman және басқалар 2000). Жалпы алғанда, қазақстандық университеттердің басқару моделі әлі де құқықтық және ұйымдастырушылық тұрғыдан жетілдіруді қажет ететінін байқауға болады.

Жоғарыда қарастырылған мәселелердің негізінде келесідей ұсыныстар жасалады:

Біріншіден, жаһанданудың жоғары білім саласына ықпалына қатысты ғылыми әдебиетті және жекелеген елдердің тәжірибесін тереңірек зерттеу қажет. Мұндай зерттеу жұмыстары келешекте реформа жүргізуде қателіктерге бой алдырмау үшін маңызды. Бүгінгі таңда Қазақстанның жоғары білім саласында аса күрделі реформалар жүргізілуде және оның маңыздылығы 
әлі де көпшілікке мәлім емес. Еліміздің білім мен ғылымның болашағына балта шаппау үшін 1970 жылдары Латын Америкасы елдерінде орын алған саяси және экономикалық бағдарламалардағы қателіктерді зерттеуіміз қажет.

Екіншіден, ұлттық және мемлекеттік университеттердің басқару жүйесіне қатысты осыған дейін жүргізілген реформалардан қандай пайда болғаны не болмағаны туралы ақпарат берілу керек. Университетің басқару моделінің тиімділігіне баға беретін критерийлер жасап шығару керек. Бүгінгі таңда жасалып жатқан реформалардың мемлекеттік және ұлттық университеттердің болашағы үшін маңыздылығы аса жоғары болғандықтан, реформаны жасаушылар кімдер және олардың көздеген мақсаты не және ұсынған концепциясымен таныстыру керек. Бұл реформалар ғылыми ортада кеңінен талқылауға түсуі қажет.

\section{Қорытынды}

Зерттеу жұмысының нәтижесінде жаһанданудың жоғары білім саласына ықпалы және оның жекелеген елдердің білім жүйесінде көрініс табуы туралы бірқатар мамандар мен зерттеушілердің еңбектері талданды. Жоғары білім саласындағы жаһандану саясаты неолибералдық концепциямен ұштасып отырғаны және ол Батыстың дамыған елдерінің бастамасымен жүзеге асырылғаны анықталды. Жоғары білім саласында неолибералдық идеялардың таралуына Вашингтон Келісімі және өзге де халықаралық ұйымдардың қатысы бар екенін көріп отырмыз. Жоғары білім саласындағы мәселелерді нарықтық қатынастар арқылы шешу идеясы АҚШ-тың экономист ғалымдарының кеңес беруімен жасалғаны және ол Американың экономикалық үстемдігін орнатуға бағытталғаны туралы тұжырымдар жасалды. Қазақстандық университеттер Еуропалық жоғары білім кеңістігіне еніп, Болон процесі шеңберінде түрлі реформаларды басынан өткеріп жатқаны айтылды. Жалпы алғанда, жаһандану процесі қазақстандық университеттерге әлемдік білім кеңістігіне есік ашып, алдыңғы қатарлы университеттермен әріптестік орнатуға мүмкіндік берді, білімнің сапасы халықаралық стандарттарға сәйкес бағаланатын болды. Алайда, жаһанданудың ұлттық білім жүйесіне келтіретін кері әсері бар екені де көрсетілді.

Қазақстанның жоғары білім жүйесіне Болон процесінің ықпалы зор болғаны және Батыстың алдыңғы қатарлы университеттерінің басқару моделі еліміздің жекелеген университеттерінде енгізіліп жатқаны көрсетілді. Алайда, қазақстандық контексте университеттік басқару жүйесінде жүргізілген зерттеу жұмыстары өте аз екені анықталды және университеттік басқару моделіне қатысты мәселелерді қарастыруда Батыстың ғылыми әдебиетіне сілтеме жасап, корпоративтік басқару теорияларына сүйеніп талдау жасалды. Басқару жүйесінің тиімді қызмет етуі университеттің жалпы тиімділігіне ықпал ететін басты фактор екені және бұл бағытта қазақстандық университеттерде әлі де жетілдіру жұмыстары жүргізілу қажеттігі ұсынылды.

\section{Әдебиеттер}

Altbach P.G. (2004) Globalisation and the university: Myths and realities in an unequal world. Tertiary Education and Management, 10(1), 3-25.

Anafinova, S. (2020) The role of rankings in higher education policy: Coercive and normative isomorphism in Kazakhstani higher education. International Journal of Educational Development, 2020, 78, 102246.

Әбдірәсілқызы А. (2013) Қазақстандағы діни білім жүйесі: тарихы, қазіргі жай-күйі және өзекті мәселелері. / https:// kazislam.kz/eislam-153/

Berg E. (1994) Poverty and Structural Adjustment in the 1980s: Trends in Welfare Indicators in Latin America and Africa / E. Berg. - Bethesda. Md., DAI.

Branford S. (1988) The Debt Squads: The US, the Banks and Latin America / S. Branford, B. Kucinski. - London: Zed Books.

Bilyalov, B. (2018) Organizational Socialization and Job Satisfaction of Faculty at Nazarbayev University in Kazakhstan, European Education, 50:3, 229-248, DOI: 10.1080/10564934.2017.1401436

Bologna Declaration of 19 June 1999 / http://www.ehea.info/media.ehea.info/file /Ministerial_conferences/02/8/1999_Bologna_Declaration_English 553028.pdf

Dixon, K \& Coy, D. (2007) 'University Governance: Governing Bodies as Providers and Users of Annual Reports', Higher Education, vol. 54, no. 2, pp. 267-91.

Dobbins M., Knill C. and Vögtle E. (2011) An analytical framework for the cross-country comparison of higher education governance. Higher Education, Vol. 62, No. 5, pp. 665-683 Published by: Springer 
Donaldson, T \& Preston, L.E. (1995) 'The Stakeholder Theory of the Corporation:Concepts, Evidence and Implications', Academy of Management Review, vol. 20, no. 1, pp. 65-91.

Edwards, M. (2000) 'University Governance: A Mapping and Some Issues', paper presented to LifeLong Learning Network National Conference, Melbourne, December, <http://www.atem.org.au/pdf/Governance.pdf $>$.

European Commission. (2003) Higher Education in Europe. Available at: http://europa.eu.int/comm/education/ higher.html (accessed 5 April 2010).

Glewwe, P. (2014) Education Policy in Developing Countries. Chicago: University of Chicago Press.

González, Cristina. (2013) Chile: Higher Education: A Canary in a Privatisation Coalmine. University World News, 295, November 8.

Giroux, H.A. (2002) Neoliberalism, corporate culture, and the promise of higher education: the university as a democratic public sphere. Harvard Educational Review, 72(4), 425-463.

Harvey, D. (2005) A brief history of neoliberalism. New York: Oxford University Press, 2005.

Hillman, A.J., Canella, Jr., A.A. and Paetzold, R.L. (2000) The Resource Dependence Role of Corporate Directors: Strategic Adaptation of Board Composition in Response to Environmental Change, Journal of Management Studies, 37 (2), $235-255$.

Hursh, D., \& Wall, A.F. (2011) Repoliticizing higher education assessment within neoliberal globalization. Policy Futures in Education, 9(5), 560-572.

Huisman, J., Smolentseva, A., Froumin, I. (Eds.). (2018) 25 Years of Transformations of Higher Education Systems in PostSoviet Countries. Reform and Continuity. Palgrave Macmillan. 482 p.

Қабидолла, Р., Өтемұрат, О., Асанкелдіұлы, А. Ғалымжанқызы, С. (2020) Замана зұлматы: Ашаршылық кезеңдері бөлек қаралуы тиіс //egemen.kz

Қазақстан Республикасында білім беруді және ғылымды дамытудың 2020-2025 жылдарға арналған мемлекеттік бағдарламасын бекіту туралы / Қазақстан Республикасы Үкіметінің 2019 жылғы 27 желтоқсандағы № 988 қаулысы

Marginson, S., \& Mollis, M. (2001)'The door opens and the tiger leaps': Theories and reflexivities of comparative education for a global millennium. Comparative Education Review, 45(4), 581-615.

Nazarbayev University Strategy 2013-2020 // https://nu.edu.kz/wpcontent/uploads/2016/09/NU_strategy_-final-1.pdf

Nybom, T. (2003) The Humboldt legacy: Reflections on the past, present and future of the European university. Higher Education Policy, 2003, 16, 141-159.

Olsen, J. (2007) The institutional dynamics of the European University. In M. Peter \& O. Johan (Eds.), University Dynamics and European Integration. Dordrecht: Springer.

OECD Reviews of National Policies for Education (2017) Higher Education in Kazakhstan // https://www.oecd.org/publications/ higher-education-in-kazakhstan-2017-9789264268531-en.htm

Parjanadze, N. (2009) Globalisation theories and their effect on education. IBSU Scientific Journal, 2009, 2(3), 77-88.

Phillips, D. and Schweisfurth, M. (2014) Comparative and International Education: An Introduction to Theory, Method, and Practice. London: Bloomsbury.

Постановление Правительства Республики Казахстан от 11 октября 2019 года № 752 О некоторых вопросах высших учебных заведений Министерства образования и науки Республики Казахстан / https://online.zakon.kz

Robertson S., Novelli M., Dale R., Tikly L., Dachi H. and Alphonce N. (2007) Globalisation, Education and Development: Ideas, Actors and Dynamics. London: DfID.

Robertson S. (2010) The EU, 'regulatory state regionalism' and new modes of higher education governance, Globalisation, Societies and Education, 8:1, 23-37, DOI: 10.1080/14767720903574033

Tikly, L. (2004) Education and the new imperialism. Comparative Education, 40(2), 173-198.

Van der Wende, M. (2004) Introduction. On cooperation and competition: National and European Policies for the Internationalisation of Higher Education. Lemmens, Bonn.

Verger, A. (2012) "Framing and Selling Global Education Policy: The Promotion of Public-Private Partnerships for Education in Low-Income Contexts.” Journal of Education Policy, 27 (1): 109-30.

Waters, M. (1995) Globalization. London: Routledge.

\section{References}

Altbach P. G. (2004) Globalisation and the university: Myths and realities in an unequal world. Tertiary Education and Management, 10(1), 3-25.

Anafinova, S. (2020) The role of rankings in higher education policy: Coercive and normative isomorphism in Kazakhstani higher education. International Journal of Educational Development, 2020, 78, 102246.

Abdirasilqızı A. (2013) Qazaqstandağı dinï bilim jüyesi: tarïxı, qazirgi jay-küyi jäne özekti mäseleleri (Abdrasilovna A. (2013)

The system of religious education in Kazakhstan: history, current status and current issues) / https://kazislam.kz/eislam-153/

Berg E. (1994) Poverty and Structural Adjustment in the 1980s: Trends in Welfare Indicators in Latin America and Africa / E.

Berg. - Bethesda. Md., DAI,.

Branford S. (1988) The Debt Squads: The US, the Banks and Latin America / S. Branford, B. Kucinski. - London: Zed Books. Bilyalov, B. (2018) Organizational Socialization and Job Satisfaction of Faculty at Nazarbayev University in Kazakhstan,

European Education, 50:3, 229-248, DOI: 10.1080/10564934.2017.1401436

Bologna Declaration of 19 June 1999 / http://www.ehea.info/media.ehea.info/file /Ministerial_conferences/02/8/1999

Bologna_Declaration_English_553028.pdf 
Dixon, K \& Coy, D. (2007) 'University Governance: Governing Bodies as Providers and Users of Annual Reports', Higher Education, vol. 54, no. 2, pp. 267-91.

Dobbins M., Knill C. and Vögtle E. (2011) An analytical framework for the cross-country comparison of higher education governance. Higher Education, Vol. 62, No. 5, pp. 665-683 Published by: Springer

Donaldson, T \& Preston, L.E. (1995) 'The Stakeholder Theory of the Corporation:Concepts, Evidence and Implications', Academy of Management Review, vol. 20, no. 1, pp. 65- 91.

Edwards, M. (2000) 'University Governance: A Mapping and Some Issues', paper presented to LifeLong Learning Network National Conference, Melbourne, December, <http://www.atem.org.au/pdf/Governance.pdf $>$.

European Commission. (2003) Higher Education in Europe. Available at: http://europa.eu.int/comm/education/ higher.html (accessed 5 April 2010).

Glewwe, P. (2014) Education Policy in Developing Countries. Chicago: University of

Chicago Press.

González, Cristina. (2013) Chile: Higher Education: A Canary in a Privatisation Coalmine. University World News, 295, November 8.

Giroux, H.A. (2002) Neoliberalism, corporate culture, and the promise of higher education: the university as a democratic public sphere. Harvard Educational Review, 72(4),

425-463.

Harvey, D. (2005) A brief history of neoliberalism. New York: Oxford University Press.

Hillman, A.J., Canella, Jr., A.A. and Paetzold, R.L. (2000) The Resource Dependence Role of Corporate Directors: Strategic Adaptation of Board Composition in Response to Environmental Change, Journal of Management Studies, 37 (2), $235-255$.

Hursh, D., \& Wall, A.F. (2011) Repoliticizing higher education assessment within neoliberal globalization. Policy Futures in Education, 9(5), 560-572.

Huisman, J., Smolentseva, A., Froumin, I. (Eds.). (2018) 25 Years of Transformations of Higher Education Systems in PostSoviet Countries. Reform and Continuity. Palgrave Macmillan. $482 \mathrm{p}$.

Qabïdolla, R., Ötemurat, O., Asankeldiulı., A. Ğalımjanqızı., S. (2020) Zamana zulmatı: Aşarşılıq kezeñderi bölek qaralwı tïis. (Kabidolla, R., Utemurat, O., Asankeldievich., A. Galymzhanovna., S. (2020) Darkness: Periods of famine should be considered separately.) //egemen.kz

Qazaqstan Respwblïkasında bilim berwdi jäne ğılımdı damıtwdıñ 2020-2025 jıldarğa arnalğan memlekettik bağdarlamasın bekitw twralı / Qazaqstan Respwblïkası Ükimetiniñ 2019 j1lğ 27 jeltoqsandağ1 № 988 qawlısı (State program of development of education and science in the Republic of Kazakhstan for 2020-2025 / the order of the Government of the Republic of Kazakhstan from December 27, 2019 № 988)

Marginson, S., \& Mollis, M. (2001)'The door opens and the tiger leaps': Theories and reflexivities of comparative education for a global millennium. Comparative Education Review, 45(4), 581-615.

Nazarbayev University Strategy 2013-2020// https://nu.edu.kz/wpcontent/uploads/2016/09/NU_strategy_-final-1.pdf

Nybom, T. (2003) The Humboldt legacy: Reflections on the past, present and future of the European university. Higher Education Policy, 2003, 16, 141-159.

Olsen, J. (2007) The institutional dynamics of the European University. In M. Peter \& O. Johan (Eds.), University Dynamics and European Integration. Dordrecht: Springer.

OECD Reviews of National Policies for Education (2017) Higher Education in Kazakhstan // https://www.oecd.org/publications/ higher-education-in-kazakhstan-2017-9789264268531-en.htm

Parjanadze, N. (2009) Globalisation theories and their effect on education. IBSU Scientific Journal, 2009, 2(3), 77-88.

Phillips, D. and Schweisfurth, M. (2014) Comparative and International Education: An Introduction to Theory, Method, and Practice. London: Bloomsbury.

Postanovleniye Pravitel’stva Respubliki Kazakhstan ot 11 oktyabrya 2019 goda № 752 O nekotorykh voprosakh vysshikh uchebnykh zavedeniy Ministerstva obrazovaniya i nauki Respubliki Kazakhstan (Resolution of the Government of the Republic of Kazakhstan dated October 11, 2019 No. 752 On some issues of higher educational institutions of the Ministry of Education and Science of the Republic of Kazakhstan) / https://online.zakon.kz

Robertson S., Novelli M., Dale R., Tikly L., Dachi H. and Alphonce N. (2007) Globalisation, Education and Development: Ideas, Actors and Dynamics. London: DfID.

Robertson S. (2010) The EU, 'regulatory state regionalism' and new modes of higher education governance, Globalisation, Societies and Education, 8:1, 23-37, DOI: 10.1080/14767720903574033

Tikly, L. (2004) Education and the new imperialism. Comparative Education, 40(2), 173-198.

Van der Wende, M. (2004) Introduction. On cooperation and competition: National and European Policies for the Internationalisation of Higher Education. Lemmens, Bonn.

Verger, A. (2012) "Framing and Selling Global Education Policy: The Promotion of Public-Private Partnerships for Education in Low-Income Contexts.” Journal of Education Policy, 27 (1): 109-30.

Waters, M. (1995) Globalization. London: Routledge. 